JMKSP (Jurnal Manajemen, Kepemimpinan, dan Supervisi Pendidikan)

Volume 6 Issue 2 (2021) Page 352-371

ISSN 2614-8021 (Online) 2548-7094 (Print)

\title{
The Potential of Islamic Boarding Schools and Their Effort of Development and Fostering at Pesantren Persatuan Islam 1-2 Bandung
}

\author{
Asep Abdul Aziz ${ }^{1}$, Nurti Budiyanti² ${ }^{2}$ Nurwadjah Ahmad ${ }^{3}$, \\ Andewi Suhartini ${ }^{4}$ \\ ${ }^{1,3,4}$ Universitas Islam Negeri (UIN) Sunan Gunung Djati Bandung \\ ${ }^{2}$ Universitas Pendidikan Indonesia \\ Corresponding Author E-mail: asepabdulaziz1993@gmail.com
}

Received 15 June 2021; Revised 21 June 2021; Accepted 25 June 2021

\begin{abstract}
The existence of boarding schools in Indonesia, in its development and coaching was very influential to the surrounding community, especially in terms of education. The world education was now facing a case of moral degradation great increasingly. The presence of Pesantren educational institutions can certainly strengthen Islamic civilization. The researchers used qualitative approach with case study methods at Pesantren Persatuan Islam 1-2 Bandung. The results of the study showed that Pesantren Persatuan Islam 1-2 Bandung was one of the modern pesantren that combines religious science and general science. Pesantren has the potential to give birth to students who are independent, sincere, tolerant, simple, and can establish a good ukhuwah ilsmaiyaah. The result has proven from the coaching program that was done either at KBM hours or outside KBM. The effort construction carried out in outside the KBM were ikhtifal activities, bai'at activities, hadith research activities, tahsin wa tahfidz halaqah activities, as well as Arabic language worship activities. While the efforts construction on KBM were adjusted in existing subjects both containing the general curriculum of IPA and IPS programs, the central religious curriculum (akidah akhlak, al-quran, Islamic cultural history, and fiqh), as well as pesantren curriculum such as balaghah, mantiq, maani, hiwar, ushul fiqh, tafsir ahkam, fafsir aam, aqidah, nahwu sharaf, and falaq science). All subjects are directed to embody a generation that is tafaquh fid-in.
\end{abstract}

Keyword: The Potential Islamic Boarding School; Development Pesantren, Fostering Pesantren 


\section{Introduction}

The education character is currently experiencing extremely severe crisis, based on a review of literature review. One of the causes of this moral decline is the educational paradigm which tends to be cognitive aspects only, even though the success of education is not only seen in the cognitive realm, but in the spiritual realm that can form good moral aspects in students (Syafe'i 2017; Kritiawan, et al., 2017; Bahri, et al., 2021). Character building must be carried out continuously involving aspects of knowledge, feeling, loving and action (Herdiana 2013; Cahyono, et al., 2018). Islamic boarding schools have also been one of the institutions that have been implementing education character for a long time. Pondok Pesantren one of the sub-systems Education seen by many as having advantages and characteristics specialized in applying the education character for students to continue to build the nation's morality. The development process of boarding institutions must have the support and attention from the government as process of human development (Budiyanti et al. 2020). Efforts to play the role of pesantren in enhancing and developing regional autonomy are a very strategic in improving the education sector as an effort to national development. Moreover, the condition of a very worrying moral crisis is suffered by the nation's future children (Budiyanti, Aziz, and Palah, 2020).

The existence of Islamic boarding schools as an Islamic educational institution has a strategic position and is relatively influential in the scientific world (Bashori, 2017). The existence of pesantren develops moral values and becomes an alternative to adapt to the needs of society (Alwi, 2016). The existence of the cottage schools, in Indonesian the development is very influential of surrounding communities, especially in terms of education (Solomon, 2016). It is due to the fact that from since beginning of establishment of pesantren prepared to educate and to spread of Islamic teachings to the community through recitation, either traditional or modern systems (Nihwan 2017). Pesantren generally have similarities between one pesantren and another, namely the existence of ideological similarities and having the same references in applying teaching methodologies, so that the pesantren has significant strength and can be taken into account by anyone (Adnan Mahdi, 2005). Pesantren has proven itself as an Islamic educational institution established and able to improve the generation of people, because schools have a strategic position in the world of education in Indonesia (Siyono, 2021). So far, social, political, cultural and other changes do not seem to have much influence on the existence of pesantren. He gives his own 
touch to the community. This has been proven by Islamic boarding schools in the form of a major contribution to the spirit of educating the nation's generation and strengthening civilization. Pesantren are have dual function: first, as an institution education religious that serves to disseminate and develop sciences religion. Secondly, as an institution cadre managed print cadre people and nation. Generally cadres of the gain social recognition (social recognition) widely. Thirdly, pesantren as agent social reforms that changes and improvements in the life community. It is last point because schools with figure a central clerics have influence strong in around society, so that to do mobilization rapid and effective (Sulaiman, 2019).

In carrying out this role, it is important that examined Islamic boarding school or pesantren related to its potential, development, and guidance in realizing of tafaquh fid-din generation. Pesantren Persatuan Islam 1-2 Bandung was chosen as one of the modern Islamic boarding schools that combined a religious curriculum with a general curriculum in which there is a system of development and guidance that is different from the others. This particularity can actually be used as material for analysis in realizing a strong Islamic civilization.

\section{Methods}

This study aimed to get an idea of the potential of boarding and attempts and fostering development in the Union of Islamic Boarding School 1-2 Bandung. This research used a qualitative approach with a case study method. In research data was searched on the potential of Islamic boarding schools and the development and the guidance peantren, which became the object of the case study focused on Islamic Boarding School at Pesantren Persatuan 1-2 Bandung. Case study was a strategy that empirical investigating a phenomenon in a real life. This strategy included qualitative evidence that relies on multiple sources of and previous developments of theoretical propositions. The researchers collect, identify, analyze, and organize the data synthesis, and then give an interpretation of the potential boarding schools and development efforts as well as supporting them at Pesantren Persatuan Islam 1-2 Bandung.

\section{Results and Discussion}

\section{Potential Generation Print Boarding School in Fataquh Fid-Deen}

Pesantren is oldest educational institution in Indonesia. Pesantren is a traditional educational institution in Indonesia whose history has been rooted for 
centuries distant before Indonesia independence and before the Islamic kingdom stand (Busahdiar, 2016). The terms pesantren and pondok are two words which cannot be separated, because every discussing pesantren means we are discussing the concept of a cottage (Anwar, 2015). Thus, before explaining understanding boarding, means need to explain the meaning of the word cottage. Etymologically the term cottage is actually derived from the Arabic, which means the house lodging, bedroom, dorm, or a simple guesthouse (Herman 2013). The is terminological said cabin is often understood as a shelter simple for students or students that are far from the place of origin. Meanwhile Sugarda Poerbawakatja in the opinion of the cottage is a place of lodging for young follow subjects Islamic religion. The is simplicity and temporary shelter for prosecution of science (Maesaroh and Achdiani, 2018).

Interest establishment of cottage pesantren are: (1) Print scholar who mastered science-ilmu religion. (2) Educate Muslims could carry out religious laws. (3) Educate that the object has a basic skills relevant to the formation of religious communities. Meanwhile, the specific goal is to prepare students to become pious people in the religious knowledge taught by the kyai concerned and to practice them in society (Zulhimma, 2013). Thus the educational goals of pesantren are to produce students who are tafaquh fid deen (understand religion), able to develop their intellectual, emotional and spiritual potential well in everyday life (Shofiyyah, Ali, and Sastraatmadja, 2019; Tolib, 2015).

Boarding school has special characteristics that are different from other educational institutions, as well as having a strong potential in giving birth to generations of people who have good morals, among the potentials that can be generated in Islamic boarding schools are: (1) Independence: independent behavior is the ability of students to take and carry out decisions freely. Associated with the habits of students is routine of indicates tendencies students more capable and daring intake and execute decisions by independent (2) Sincerity: all actions undertaken students must begin with a sincere intention directed untu achieve the pleasure of Allah (Abdullah 2013). (3) Tolerance: tolerance is seen to be the glue of national unity Indonesia must be nurtured properly (Ma'mun, 2016). (4) Simplicity: simple here does not mean passive, poor, or poor, but it contains elements of willpower, fortitude, and restraint in facing as kinds obstacle life which is expected to rise a great soul, daring, stir forward, and never back down under all circumstances (Sulaiman, 2019). (5) of the Islamic brotherhood; atmosphere of the cottage boarding always filled with 
spirit of brotherhood a very familiar so thick and seemed to be felt along of course, there are many religious values that have become familiar in it (Siregar, 2018). Thus, the potential of this potential that must be constantly nurtured in boarding school, as this is where the initial growing strength mental and character is a requirement for the success of the struggle in all areas of life.

Pesantren Persatuan Islam 1-2 Bandung which is located in the City of Bandung has the same potential in realizing the generation tafaquh fid-din. This can be seen from a goal of pesantren education institutions in general, namely: "The leading educational institutions realization of Islamic boarding schools as miniature Islamic societies and". As for specifically, the objectives of the pesantren are (1) to become a human being who is tafaquh fid diienlaw (2) to practice Islamic in everyday life (3) to become role models for families and society (4) to master the basics of Islamic teachings from the source (5) preach Islamic teachings based on the Koran and Sunnah (6) mastering knowledge related to education and teaching theoretically and practically. The vision is to develop human beings withwho are blessed qualities Tafaqquh Fiddien and master science and technology. As indicators of the pesantren's mission are: (1) Insan Berahlaqul Karimah : behave according to ahlaqul karimah, be independent, confident, and creative. (2) Insan Tafaqquh Fiddien: master and understand the sciences of Islam, memorize and understand the Koran and Hadith. (3) Individuals who master science and technology: master science and science, as well as mastering information and communication technology.

\section{An efforts to Develop the Generation Tafaquh Fid-Diin at the Islamic Association 1-2 Islamic Bandung 1-2}

Islamic Boarding School have tried to realize the generation Tafaquh FidDiin through various curricula presented in the coaching process (input), there is a religious curriculum from the center, a general curriculum also the pesantren curriculum, so as to produce a generation that not only understands religion, but can make many contributions in every aspect of life, such as economics, politics and da'wah. This is of course influenced by the good management that is managed at the pesantren, because every in the pesantren is involved stakeholder in creating an Islamic culture in accordance with the vision and mission of the Islamic Boarding School 1-2 Bandung. Alumni also often make positive contributions in advancing the economy of Islamic boarding schools and provide many facilities in encouraging the spread of Islamic da'wah. As stated by educational experts, the 
success of a boarding school needs to be supported by good management. Management improvement Quality boarding that applies the principles of quality to ensure specifications quality as defined manner. Comprehensive and sustainable a quality management approach conducted by a thorough, startinginputs, outputs, and outcomes. In the world of education out comes associated with the involvement of alumni in management and the development of educational institutions. All system components organizations are positioned as part of guaranteeing the quality and synergized through leadership Quality (Fathurrohman. 2012).

In management traditional generally No three functions, principal management including planning, implementation, and evaluation. Meanwhile, Joseph Juran, as quoted by Daulat P. Tampubolon, said that management has three functions, namely: quality planning, quality control, and quality improvement. In every activities pesantren then the basic framework that is raised is quality planning, namely processes identification needs in fields objectively. The translation needs to programs activities and preparation of implementation steps. So that at the level of practice, schools need to do a focus on the needs in the field include: (1) Reability (Trust), which are services corresponds to the desired. (2) Assurance, which means being able to guarantee quality of services provided. (3)Tangible (appearance), namely a conducive climate for pesantren. (4) Emphaty (Attention), namely giving full attention to the students as the customers main. (5) Responsiveness, which is responsive to the needs of students (Fathurrohman 2012; Ulum, et al., 2021).

In order to imply the concept of quality improvement management based on this pesantren, then through active and dynamic participation from parents, students, religious teachers, and other pesantren employees, including institutions that have concern for Islamic educational institutions (pesantren). In order for the implications of theTotal Quality Management (TQM) program in Islamic boarding schools to run as expected, the following requirements are needed: (1) High commitment from top management. (3) Allocating full time for the Total Quality Management (TQM) program. (4) Prepare funds and prepare quality human resources. (5) Select a TQM program coordinator. (6) Perform other companies that implement TQM. (7) Formulate values, vision and mission. (8) Preparing mentally to face various forms of obstacles. (9) Planning the mutation of the TQM program (Fathurrohman 2012; Umam, et al., 2021). 
In this regard, Burhanuddin asserted also that management has aposition strategic to gives support the provision of education, particularly in programs to improve the quality of education in schools (cottage). Management works in the process utilizing all available resources in the school as optimally as possible for the implementation of educational programs effectively and efficiently. There are several aspects of the development that need to be known in the development of the boarding school, the Human Resources Development boarding school, boarding school management development, technology development lodge, boarding development cottage economic pesantren (Halim, 2005). The development of this pesantren must be considered well considering that there are a lot of research results which describes situations pesantren that need to be developed again to become better.

Reality now there are some things that facing schools in the conduct of the development, namely: (1)Image pesantren, as institution traditional, not modern, informal and even as an institution that created terrorism, These things have influence if people to leave the boarding school world. (2) Facilities and infrastructure supporting looks is still inadequate. Not only in terms instructor buildings that must be addressed, but there is also that is still cottage room shortage (dorms) as a place of settlement students. (3) Human resources, although human resources in the religious field cannot be doubted, in order to improve the existence and role of Islamic boarding schools in the field of social life, serious attention is needed. (4) Increased access and networking is one needs for the development of pesantren. (5) institutional management, management is an important element in the management of schools. At this time, it is still seen that the boarding school is managed traditionally. (6) The independence of the institutional economy, financial needs become obstacles in carrying out Islamic boarding school activities, both related to development and daily activities. (7) A curriculum that is oriented towards the life skills of students and society. Some of these things need to be considered and become the spotlight so that the pesantren curriculum can develop according to the times.

Analysing development process at the Islamic Boarding School 1-2 Bandung in response to the above, there are several efforts that are always made by the pesantren, namely: (1) Related to the image of the pesantren: This Islamic boarding school is a modern Islamic boarding school that always combines religious and general lessons, and now this pesantren is designing technologybased learning because it adapts to the times. (2) With regard to facilities and 
infrastructure: This pesantren is trying to add to the facilities for the learning process by expanding the area of the mosque, the area of the santri association, the balcony for students to memorize the Al-Quran. Previously there were adequate facilities provided at the Islamic Boarding School 1-2 Bandung, there were separate accommodation areas for students and brothers, learning process room, laboratory room, hall room, teacher room, administration room, special room for mosque management and sports fields, or commonly used for santri activity activities. (3) With regard to human resources: This Islamic boarding school has sufficient quality and quantity of resources, it's just that it needs structured guidance so that the kiai and ustadz in the pesantren can utilize digital media in the learning process, keeping up with the times. (4) Relating to increased access and networking : This pesantren has quite a lot of access, because of the strategic location of the pesantren in urban areas. Moreover, this Islamic boarding school is the first and second Islamic Unity Islamic Boarding School in Bandung. (5) With regard to institutional management: This pesantren has good management and is managed according to the times, but has not yet been maximally developed digitally. (6) With regard to economic independence: This conference does not have its own economic institutions, only contributions from alumni. Thus, economic independence is needed by establishing a special economic institution to develop Islamic da'wah at the Islamic boarding school. (7) Regarding the curriculum: This Islamic boarding school has a good curriculum to continuously develop the life skills of students, it is necessary to add life skills in the digital field, so that the Islamic boarding school can still maintain its existence in the current 4.0 industrial revolution.

Coaching students is attempts to maintain, preserve and perfect humans in this case, students are to become figures who have straight morals (Hidayat, Rizal, and Fahrudin 2018). In providing guidance on morality there are three things that must be given educators to learners to understand, appreciate and practice the teachings of Islam thoroughly. these three things are education of aqidah, worship education, education of morality (Syukir 1992, p. 20). This must be built in coaching activities at Islamic boarding schools, so that students have intellectual intelligence, emotional intelligence, social intelligence, and spiritual intelligence (Budiyanti, Aziz, and Indonesia 2020); (Budiyanti, Rizal, and Sumarna 2016). Which in the end can form a perfect human being in the hope of Allah (Budiyanti, Aziz, and Palah 2020). 
Pesantren Persatuan Islam 1-2 Bandung is a modern Islamic boarding school that combines religious and general knowledge. So that in the implementation of coaching at the pesantren, it combines the teachings of the Koran and Hadith as the main foundation reinforcement. As frozen by educational experts that in the effort to guide students there must be some rules and norms set by the educational institution, there are at least five elements that must be present in an educational institution, namely: (1) rules as a code of conduct, (2) habits, (3) laws for violating rules, (4) rewards for good behavior in accordance with applicable regulations, and (5) consistency in carrying out the rules both in giving punishment and in reward. The Islamic Unity Pesatren as an educational institution that aims to realize the generation tafaquh fid-din has these five elements, as this can be seen from the process of guidance carried out in pesantren institutions, both in teaching and learning activities and outside the teaching and learning activities.

\section{An Efforts to Generation of Foster the Tafaquh Fid-Diin at Islamic Unity Islamic Boarding School 1-2 Bandung}

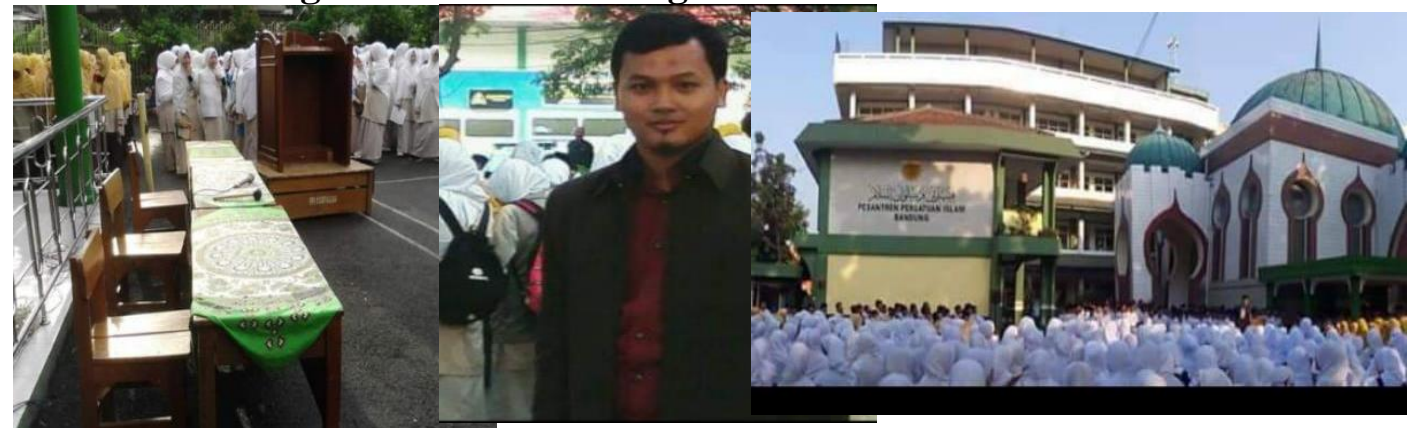

Figure 1. Development of Pupils Ikhtifal PPI 1-2 Bandung

Development generation of tafaquh fid-deen done in Pesantren Persatuan Islam 1-2 Bandung carried out during the teaching process lasted well beyond teaching and learning process. Among the examples of coaching carried out outside the teaching and learning process taking place are as follows: (1) Ikhtifal activities carried out at the Pesantren are carried out every Thursday at 07.00, summaries are carried out in order to gather every week to listen to lectures as a spiritual shower of students, reminding them rules and regulations, informing the achievement of high-achieving students and others related to self-development. Lectures or also called muhadharah were delivered by usatadz as well as 
competent santri in rotation using Arabic. This coaching activity is expected to have a strong missionary spirit in spreading Islamic teachings in accordance with the Al-Quran and al-Hadith, as seen in Figure 1 above. (2) Bai'at carried out every day in the pesantren field which is led by ikhwah santri in rotation, before the students enter their respective classes. This is done to train the discipline of students so that they always follow the rules of the pesantren and always have an Islamic personality. The contents of the pledge in this pesantren will be visualized into the following table:

\section{Table 1: Text allegiance Students PPI 1-2 Bandung \\ Source: Books The Santri Pocket 2019-2020}

\section{Text of the Bai'at and its translation}

1. I promise to the ustadzku.

2. I will obey ustadzku.

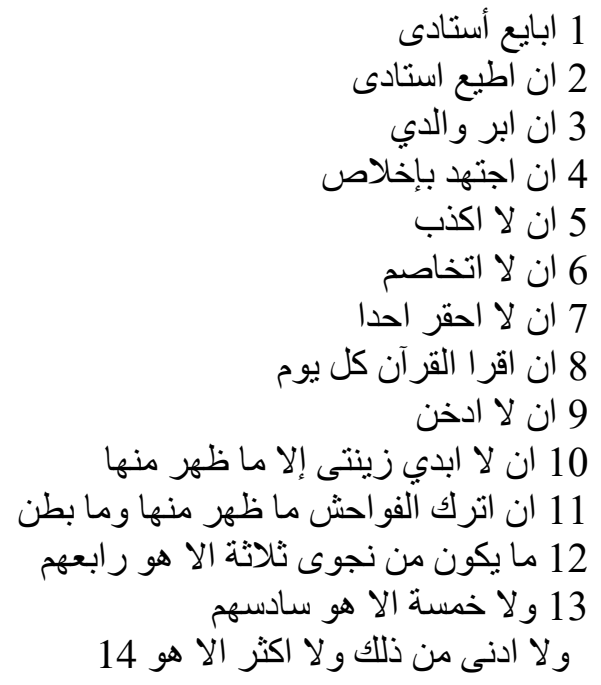

3. I will do good to my parents.

4. I will mean it with utmost sincerity.

5. I will not lie.

6. I will not fight.

7. I will not criticize someone.

8. I will read the Koran every day.

9. I will not smoke.

10

10. I will not show my jewelry except for the usual looks.

11. I will leave behind the ugliness that is visible and that which is not seen.

12. There is no secret conversation between three people, but $\mathrm{He}$ (Allah) is the fourth.

13. And there was no talk of five people, but He was the six.

14. And there is no talk of less than that or more but $\mathrm{He}$ will be with them wherever they are. 
The table above has Bai'at functions as basic to regulations Islamic boarding schools which provide reinforcement of and absorption into students by being promised once a day as parts of Islamic character building which are binding and reminder for daily life students both within the school and outside the school, both within the teaching and learning activities and outside the teaching and learning activities. The regulation circuit for an optimization of the boarding school regulation nature is not only authoritative, but wanted to give the internalization of awareness in daily students overall. Thus, the promise of these students as a guideline increase of discipline in the application of the rules that is in boarding school and known by all students at the time of admission of new students. All this was a manifestation of changes in behavior toward better in everyday life. It agrees with Arikunto (in Lazwardi, 2017) who said that the rules and rules are something to regulates behavior which is expected to occur in students. Regulation should be fulfilled learners in the classroom in lesson on going times ,including, among others: (a) listening to with well what is being said or ordered by the teacher; (b) listen to good what is said by his friends in the class; (c) do not speak without the permission of the teacher; (d) giving answers if the teacher asks questions; (e) not eating or drinking if the teacher does not allow it; (f) does not come out of class if not no permission of the teacher; (g) Doing things deviate from teaching and learning activities must the teacher's rules and sanctions in this boarding school is as follows:

Table 2. Policies for Santri PPI 1-2 Bandung

\begin{tabular}{|l|l|}
\hline No & \multicolumn{1}{c|}{ Rules of Conduct Students } \\
\hline 1 & Each learner must attend at 06. 30 in Pesantren \\
\hline 2 & Each learner must attend allegiance or ikhtifal (apples) \\
\hline 3 & For participants students who are late will be sanctioned right away \\
\hline 4 & $\begin{array}{l}\text { Not allowed to have long hair / untidy hair for male students, tattoos, and } \\
\text { branches }\end{array}$ \\
\hline 5 & Dress in neat uniforms, with complete pesantren attributes, and black shoes \\
\hline 6 & $\begin{array}{l}\text { Uniform male students- Tucked in clothes, pants should not be tight (pencil } \\
\text { style) and stepped on }\end{array}$ \\
\hline 7 & Not allowed to wear jackets / sweaters in the pesantren environment \\
\hline 8 & $\begin{array}{l}\text { Female students' uniforms (headscarves) should not be short and tight (the } \\
\text { length of the veil covers the knees and the arms wear cuffs, skirts long covering } \\
\text { the ankles and wearing the legs) }\end{array}$ \\
\hline
\end{tabular}




\begin{tabular}{|c|c|}
\hline $\begin{array}{l}9 \\
\text { A }\end{array}$ & hood with a hat and covering the chest \\
\hline 10 & No wearing of excessive make up / accessories \\
\hline 11 & No smoking, no smoking consuming and distributing drugs and the like \\
\hline 12 & $\begin{array}{l}\text { It is prohibited to go outside during class hours, except with the permission of } \\
\text { the teacher concerned and the picket teacher }\end{array}$ \\
\hline 13 & Obliged to perform congregational prayers \\
\hline 14 & $\begin{array}{l}\text { If you are sick and have family needs, please send a notification letter or contact } \\
\text { by phone or sms to the pesantren }\end{array}$ \\
\hline 15 & $\begin{array}{l}\text { Prohibited carrying valuables / excessive money / other items that can interfere } \\
\text { with teaching and learning activities }\end{array}$ \\
\hline 16 & It is prohibited to activate the cellphone during the KBM activity \\
\hline 17 & $\begin{array}{l}\text { It is prohibited to commit immoral acts inside / outside the pesantren } \\
\text { environment }\end{array}$ \\
\hline 18 & $\begin{array}{l}\text { Any violation of the above rules will be subject to sanctions in accordance with } \\
\text { the applicable provisions }\end{array}$ \\
\hline 19 & igs that have not been regulated in the above order will be determined later \\
\hline
\end{tabular}

Table 3. Santri Sanctions PPI 1-2 Bandung

\begin{tabular}{|l|ll|}
\hline No & \multicolumn{2}{|c|}{ Sanctions } \\
\hline 1 & Oral Warning \\
\hline 2 & Written Warning \\
\hline 3 & Deduction \\
\hline 4 & Academic Penalties: \\
& 1. & Grading does not increase / pass \\
& 2. & Cancellation of graduation / passing \\
& 4. & Repetition of assignments \\
& 5. & Costponement of issuance of certificates \\
& \multicolumn{2}{|c|}{ Cancellation and revocation of certificates } \\
\hline 5 & Administrative penalties \\
& 1. & Suspended as pesantren students \\
& 2. & Dismissal as Islamic boarding school students \\
\hline
\end{tabular}


(3) Hadith Research Activities, hadith research activities carried out at this Islamic boarding school is a training that is carried out once a week, so that students can think critically and can also practice the hadith in accordance with what exemplified by the Prophet. (4) The Halaqah Tahsin Wa Tahfidz, activitythis halaqah activity is carried out twice a week, this activity aims to make students able to read the Koran properly in accordance with the rules of recitation and akharijul letters, then understand it, memorize it, and practice it properly and correctly. (5) Arabic Language activities, this activity is a mandatory activity that must be mastered by students, this activity is carried out once a week, and this activity is developed into Nadi Al-Arabi (an Arabic language club) which of course has a structured training agenda.

The various agenda of activities outside of the KBM hours are coaching efforts carried out at the 1-2 Islamic Unity Islamic Boarding School in Bandung. Apart from that, when the teaching and learning activities took place, all existing subjects included the general curriculum for science and social studies programs, the central religious curriculum (akidah, morals, al-quran, Islamic cultural history, and fiqih), as well as pesantren curricula such as balaghah, mantiq, maani, hiwar, ushul fiqih, tafsir ahkam, tafsir aam, parasites aqidah, nahwu sharaf, and science falaq). All subjects are directed as efforts to foster students in order to develop intellectual intelligence, social intelligence, emotional intelligence, and spiritual intelligence.

The findings of this study showed that the potential in Islamic boarding schools was tolerance, independence, simplicity of sincerity, and ukhuwah Islamiyyah. The teaching-learning process that leads to the construction or development of the character of the students was carried out through an attitude of mutual respect, brotherhood, sincerity and simplicity. The results of this study reinforced with some earlier findings that can foster tolerance and simplicity of spirit and with their good habits in the community to itself firmly attached to each of us students or students (Sumardi, 2012; Nizarani, Kristiawan, \& Sari, 2020). Ukhuwwah Islamiyaah or the concept of brotherhood is practiced by the students in their daily life in the dormitory. Hence,when they graduate from the pesantren and live in society, the students will also practice this concept of brotherhood. Freedom is one of the unique characteristics developed in pesantren.

Santri that become role models for the surrounding community were the final reflection of the learning process at the pesantren (Nurdin, \& Naqqiyah, 
2019). Because it is the mental strength and character are prerequisite for success of Islamic civilization. As revealed by Bali \& Fadli (2019) \& Jahroh, WS, \& Sutarna, N. (2016) that mental or moral qualities will shape a person's personality which will be manifested in good actions and attitudes. The form of education thory when recognize the trilogy of character formation as revealed by Thomas Lickona, namely the concept of moral (moral knowing), moral attitude (moral feeling), and moral behavior (Lickona, 1999). Then, pesantren can be said to practice the three trilogies in their education process (Baharun, 2017; Saihu \& Rohman, 2019). They practice the moral knowing and moral feeling in the process of education and learning while they practice moral behavior in the daily life of the students through the intervention of closely scheduled and planned activities from waking up in the morning to going back to sleep at night, intervening in the activities of the students conducted in order to carry out these activities repeatedly. As the result they are accustomed to be a good behavior.

The next finding show that the development carried out in this pesantren is to improve the image of the pesantren as a modern educational institution, improving the quality and quantity of human resources, increasing access to cooperation with various parties, improving institutional quality management, and efforts to establish independent economic institutions. In the education system, the Sorogan method is actually a modern method, because the teacher or kyai and students know each other closely and the teacher really masters the material that should be taught (Tolib, 2015). Students also study and make preparations in advance. Likewise, the teacher already knows what was suitable for the student and what methods should be used specifically for dealing with the student. In addition, the sorogan method is also carried out freely (without coercion) and free from formalities. Thus, what is important is not the effort to change the sorogan method into a lecture model, as in modern education, but to innovate the sorogan into the latest sorogan method (new style). Afterward, related to economic independence, this Islamic boarding school does not have its own economic institution, only the contributions of the alumni. Thus, economic independence is needed by establishing a special economic institution to develop Islamic da'wah at the pesantren. Islamic boarding schools have the potential to empower people, especially in the economic field (Lugina, 2018; Fathoni, \& Rohim, 2019). Because doing economic empowerment is a form of proselytizing and at the same time implementing the knowledge it has in a concrete (applicable) manner (Adnan, 2018). In Islam, economy is wasilah not maqashid, Hence, economy is 
one way to achieve happiness in the world and the hereafter. This is of course in accordance with what Islam teaches that assets and economic activities are a mandate from Allah SWT.

Meanwhile, the coaching carried out at the Islamic Boarding School 1-2 Bandung is aimed at the pesantren's goal of a generation that create Tafaquh fidDiin, either in organizing teaching or learning activities or outside the teaching and learning activities. Coaching efforts carried out outside the KBM are voluntary activities, bai'at activities, hadith research activities, halaqah tahsin wa tahfidz activities, and Arabic language learning activities. Meanwhile, the guidance efforts at teaching and learning hours are adjusted to existing subjects, including the general curriculum for science and social studies programs, the central religious curriculum (akidah, morals, al-quran, Islamic cultural history, and fiqih), as well as pesantren curricula such as balaghah, mantiq, maani, hiwar, ushul fiqih, tafsir ahkam, tafsir aam, parasites aqidah, nahwu sharaf, and science falaq). Efforts to develop pesantren institutions in realizing the generation Tafaquh Fid-Diin can strengthen the goals of national education. As it should be, Islamic boarding schools always have an effort to maintain the values contained in Islamic education. Because Islamic boarding schools always open their eyes to all forms of development and progress following the times (Nihwan 2017). Thus, pesantren institutions also play a role as a "center of social change", namely agents or centers of community change. The system (input-process-output-feed back) in pesantren can be expected to produce high social value added. In pesantren, religion, ideology, politics, social, economy, culture, law and defense, even appropriate technology are all studied. Islamic boarding schools are expected to be a vehicle for improving human quality by striving to alleviate poverty, ignorance, being environmentally aware and maintaining morals or commendable morals that have been scarce due to the negative effects of changing times. Pesantren not only practice individual piety but also social piety so that it can systemically provide multi-effects and competitive advantages (Arif 2016), so as to create a strong Islamic civilization.

\section{Conclusion}

Pesantren Persatuan Islam 1-2 Bandung is a modern Islamic boarding school that combines religious and general sciences. So that in the implementation of development and coaching at the pesantren, it combines the teachings of the Koran and Hadith as the main foundation reinforcement. Islamic boarding schools 
as one of the Islamic education institutions in Indonesia have special characteristics and potentials possessed by students which include: independence, sincerity, tolerance, simplicity, and ukhuwah Islamiyyah. It is what should always be grown in the boarding school, as this is where the beginning of the growth of mental strength and character that is a requirement for the success of the Islamic civilization. The development carried out at this pesantren is to improve the image of the pesantren as a modern educational institution, improve the quality and quantity of human resources, increase access to cooperation with various parties, improve institutional quality management, and establish independent economic institutions. Meanwhile, the coaching carried out at the Islamic Boarding School 1-2 Bandung is aimed at the pesantren's goal ofa generation that is creating Tafaquh fid-Diin, both in organizing teaching and learning activities or outside the teaching and learning activities. Coaching efforts carried out outside the KBM are voluntary activities, bai'at activities, hadith research activities, halaqah tahsin wa tahfidz activities, and Arabic language learning activities. Meanwhile, the guidance efforts at teaching and learning hours are adjusted to existing subjects, including the general curriculum for science and social studies programs, the central religious curriculum (akidah, morals, al-quran, Islamic cultural history, and fiqih), as well as pesantren curricula such as balaghah, mantiq, maani, hiwar, ushul fiqih, tafsir ahkam, tafsir aam, parasites aqidah, nahwu sharaf, and science falaq). All subjects are directed as an effort to foster students in order to develop intellectual intelligence,social intelligence, emotional intelligence, and intelligence spiritual.

\section{Acknowledgement}

Acknowledgments were extended to all who contributed to this research. Thank you also expressed to all participants for their contribution in helping collect data and in testing research book products. Thank for the team JMKSP (Jurnal Manajemen, Kepemimpinan, dan Supervisi Pendidikan) that given suggestion in peer review process.

\section{References}

Abdullah, A. (2013). "Madrasah In Indonesia From The Time." Paramita 23(2): 193-207. 
Adnan, AZ (2018). Strategy for Realizing Independence in the Development and Economic Empowerment of Santri (Case Study at Pondok Pesantren Al Bahjah Cirebon). Syntax Literate; Indonesian Scientific Journal, 3(9), 1-9.

Adnan Mahdi. (2005). "History and Role of Islamic Boarding Schools in Education in Indonesia." Islamic Review : Journal of Islamic Research and Studies 2(1):

$1-20$.

http://journal.ipmafa.ac.id/index.php/islamicreview/article/view/29.

Alwi, B. Marjani. 2016. "Pondok Pesantren: Characteristics, Development, and Education System." Lantern Pendidikan : Journal of Tarbiyah and Teacher Training 16(2): 205-19.

Anwar, Ahmad Masrul. (2015). "Growth and Development of Islamic Education in the Umayyad Period." Journal of TARBIYA 1(1): 47-76. http://journal.uinsgd.ac.id/index.php/jurnal-tarbiya/article/view/137/pdf_3.

Arif, Mohammad. (2016). "The Development of Islamic Boarding Schools in the Age of Technology." Journal of Islamic Education 28(2): 307.

Baharun, H. (2017). Total Moral Quality: A New Approach for Character Education in Pesantren. Ulumuna, 21(1), 57-80.

Bahri, M. S., Mispani, M., \& Tukiran, T. (2021). Education Character Perspective of KH Hasyim and Hafidz Hasan Al-Mas' udi. Bulletin of Pedagogical Research, 1(1), 16-45.

Bali, MMEI, \& Fadli, MFS (2019). Implementation of Islamic Boarding School Educational Values in Improving Santri Mental Resilience. PALAPA, 7(1), $1-14$.

Bashori, Bashori. (2017). "Modernization of Islamic Boarding Schools." Mamangan Social Science Journal 6(1): 47.

Budiyanto, Nurti et al. (2020). "The Concept of the Ideal Man: A Theological Review And Islamic Education.” Al-Tarbawi Al-Hadith: Journal of Islamic Education 5(2): 43-67.

Budiyanti, Nurti, Asep Abdul Aziz, and the Indonesian University of Education. (2020). "The Formulation of the Goal of Insan Kamil As a Basis for The." 3(2): $1-10$.

Budiyanti, Nurti, Asep Abdul Aziz, and Palah. (2020). "The formulation of the goal of human beings as a basis for the." IJECA (International Journal of Education and Curriculum Application) 3(2): 1-10.

Budiyanti, Nurti, Ahmad Syamsu Rizal, and Elan Sumarna. 2016. "Implications of the concept of lūl 'ilmi in the Qur'an to the theory of Islamic education 
(Analytical Study of Ten Tafsr Mu'Tabarah)." TARBAWY : Indonesian Journal of Islamic Education.

Busahdiar. (2016). "Education Dynamics in Islamic Boarding Schools." Misykat al-Anwar Journal of Islamic Studies and Society 27(2): 1-12. https://jurnal.umj.ac.id/index.php/MaA16/article/view/3827.

Cahyono, H., Suhono, S., \& Khumairo, A. (2018). Pendidikan Karakter Bagi

Pelaku Pedofilia (sebuah Strategi dalam Mengatasi Amoral). JMKSP (Jurnal Manajemen, Kepemimpinan, dan Supervisi Pendidikan), 3(1), 1-19.

Fathoni, MA, \& Rohim, AN (2019, August). The role of pesantren in the economic empowerment of the people in Indonesia. In Proceedings of Conference on Islamic Management, Accounting, and Economics (Vol. 2, pp. 133-140).

Herdiana, Yus. (2013). "The Development of Character Education Model Based on Human's Natural Characteristics." : 264-71.

Herman. (2013). "History of Islamic Boarding Schools in Indonesia." Journal of Al-Ta'dib 6(2): 145-58.

Hidayat, Tatang, Ahmad Syamsu Rizal, and Fahrudin Fahrudin. (2018). "The Role of Islamic Boarding Schools as Islamic Educational Institutions in Indonesia." Ta'dib: Journal of Islamic Education.

Jahroh, WS, \& Sutarna, N. (2016, August). Character Education as an Effort to Overcome Moral Degradation. In Proceedings of the National Seminar on Educational Innovation.

Kristiawan, M., Ahmad, S., Tobari, T., \& Suhono, S. (2017). Desain Pembelajaran SMA Plus Negeri 2 Banyuasin III Berbasis Karakter Di Era Masyarakat Ekonomi ASEAN. Jurnal Iqra': Kajian Ilmu Pendidikan, 2(2), 403-432.

Lazwardi, Dedi. (2017). "Curriculum Management as the Development of Educational Goals." Al-Idara: Journal of Islamic Education.

Lickona, T. (1999). Character education: Seven crucial issues. Action in Teacher Education, 20(4), 77-84.

Lugina, U. (2018). Economic Development of Islamic Boarding Schools in West Java. Risâlah, Journal of Islamic Education and Studies, 4(1, March), 5364.

Maesaroh, Nenden, and Yani Achdiani. (2018). "The Duties and Functions of Islamic Boarding Schools in the Modern Era." Societies 7(1): 346-52. 
Makmun, HA Rodli. (2016). "Character formation based on Islamic boarding school education: Studies in Traditional and Modern Islamic Boarding Schools in Ponorogo Regency." Scholar: Journal of Education and Society 12(2): 211.

Nihwan. (2017). "Islamic Boarding School Education in Maintaining Islamic Educational Values." Journal of Religious Studies, Education and Humanities 4(1): 151-65.

Nizarani, N., Kristiawan, M., \& Sari, AP (2020). Islamic Boarding School-Based Character Education Management. Journal of Intellectualita: Islam, Social and Science, 9(1), 37-44.

Nurdin, A., \& Naqqiyah, MS (2019). Model of Religious Moderation Based on Salaf Islamic Boarding School. Islamica: Journal of Islamic Studies, 14(1), 82-102.

Saihu, S., \& Rohman, B. (2019). Character formation through a transformational learning model for students at the Nurul Ikhlas Islamic boarding school in Bali. Islamic Education: Journal of Islamic Education, 8(02), 435-452.

Shofiyyah, Nilna Azizatus, Haidir Ali, and Nurhayati Sastraatmadja. (2019). "Model of Islamic Boarding School in the Millennial Era." BELAJEA: Journal of Islamic Education 4(1): 1.

Siregar, Andre Syahbana. (2018). "History of the Development of the Islamic Education System at the Ar-Raudlatul Hasanah Islamic Boarding School in Medan City." JUSPI (Journal of the History of Islamic Civilization) 2(1): 113.

Siyono, S. (2021). Multicultural Education at Pesantren (The Study of API ASRI Islamic Boarding School at Tegalrejo Magelang). Bulletin of Science Education, 1(1), 83-90.

Sulaiman, Rusydi. (2016). "Islamic Boarding School Education: Institutionalization of Islamic Boarding School Education Institutions." 'Anil Islam 9(1): 148-74.

Sumardi, K. (2012). Portrait of Character Education at the Salafiah Islamic Boarding School. Journal of Character Education, (3).

Sumardi, K. (2019). "The Nature of Islamic Boarding School Education." Edugama: Journal of Religious Education and Social Affairs 5(1): 1-29.

Shafe'i, Imam. (2017). "Pondok Pesantren: Character Building Educational Institutions." Al-Tadzkiyyah: Journal of Islamic Education 8(1): 61. 
Tolib, A. (2015). Education in modern Islamic boarding schools. Risâlah, Journal of Islamic Education and Studies, 2(1), 60-66.

Tolib, Abdul. (2015). "Education in Integrated Modern Islamic Boarding Schools." Minutes 1(1): 60-66.

Ulum, S., Mispani, M., Jaenullah, J., \& Thohir, M. (2021). The Public Perception of Islamic Education at Wali Songo Islamic Boarding School Sukajadi Village, Bumiratu Nuban District. Bulletin of Pedagogical Research, 1(1), 187-197.

Umam, W. (2020). Kepemimpinan Kiai dalam Mengembangkan Pondok Pesantren. Attractive: Innovative Education Journal, 2(3), 61-69.

Zulhimma. (2013). "The Dynamics of Development of Islamic Boarding Schools in Indonesia." Journal of Darul 'Ilmi 01(02): 166-67. 